\title{
A comparative analysis of oil as a risk factor in Australian industry stock returns, 1980-2006
}

\author{
Evan J. McSweeney \\ School of Accounting and Finance, University of Wollongong, Wollongong, Australia \\ Andrew C. Worthington \\ Department of Accounting, Finance and Economics, Griffith University, Brisbane, Australia
}

\begin{abstract}
Purpose- This paper examines the impact of crude oil prices on Australian industry stock returns. With rising energy prices, it is important to consider oil as a pricing factor in asset pricing models.

Design/methodology/approach - Multifactor static and dynamic models consider crude oil and other macroeconomic factors as pricing factors in industry excess returns from January 1980 to August 2006. The macroeconomic factors comprise the market portfolio, oil prices, exchange rates and the term premium. The industries consist of banking, diversified financials, energy, insurance, media, property trusts, materials, retailing and transportation.

Findings - Oil prices are an important determinant of returns in the banking, energy, materials, retailing and transportation industries. The findings also suggest oil price movements are persistent. Nonetheless, the proportion of variation in excess returns explained by the contemporaneous and lagged oil prices appears to have declined during the sample period.

Research implications - Macroeconomic factors are important for multifactor asset pricing at the industry level. Apart from oil prices, the market portfolio is a significant pricing factor in all industry excess returns. Exchange rates are also an influential factor for excess returns in the banking and diversified financials industries, and the term premium as a proxy for future real activity is a priced factor in the energy, insurance and retailing industries.

Originality/value - While past studies have provided some evidence that oil prices constitute a source of systematic asset price risk and that exposure varies across industries, no recent work is known in the Australian context.
\end{abstract}

Keywords Industry returns, multifactor models, market risk, interest rate risk, exchange rate risk, commodity risk

Paper type Research paper

\section{Introduction}

At least since the development of the capital asset pricing model, a literature has sought to identify the determinants of asset prices and returns. Given the capital asset pricing model rests on the premise that assets are priced according to their covariance with the market portfolio, the increasing acceptance that other pricing factors, especially macroeconomic factors, should also be modelled has led to yet further refinements, most notably in the form of the arbitrage pricing theory. With this multifactor specification as a starting point, an increasing number of empirical studies have sought to investigate whether macroeconomic variables constitute a source of systematic asset price risk at the market and industry level [see, for instance, Poon and Taylor (1991), Antoniou et al. (1998), Faff and Chan (1998), 
Dinenis and Stailouras (1998), Elyasiani and Mansur (1998), Canova and Nicolo (2000), Choi et al. (2002), Apergis and Eleftherious (2002), Patro et al. (2002), Chaudhuri and Smiles (2004), Ryan and Worthington (2004), Erdem et al. (2005) and West and Worthington (2006)].

One macroeconomic factor that is receiving increasing empirical attention is crude oil. A key factor input, crude oil prices have the potential to dramatically alter the financial performance of national economies and the firms that operate therein. In Australia, for instance, \$6,555 million of exports in crude oil and other refinery feedstock was made in 2004/05 alongside imports of \$5,127 million in refined petroleum products (including auto gasoline, diesel fuel and aviation turbine fuel) and \$9,996 million in crude oil (ABARE, 2005). This makes crude oil both Australia's third-largest export and import by value and refined petroleum its fifteenth and fourteenth-largest export and import, respectively.

A similar picture emerges in terms of energy consumption and production. While Australia consumes about one-third of its energy production, petroleum accounts for thirty-five percent of total energy consumption (about 5,525 petajoules in 2004/05) and a bare six percent of total energy production (about 17,025 petajoules) (ABARE, 2005). Finally, at the industry level the impact of crude and refined petroleum products is even more pronounced with the relative direct requirement coefficients from input-output tables showing that 3.92 units of petroleum inputs are required to produce one unit of output in the Australian transport industry, and 3.44, 3.18 and 2.19 units in the forestry/fishing, mining and coal industries, respectively (ABS, 2001). Given the current commodity export boom, clear evidence then exists for oil input factors to have a pronounced effect on Australian financial markets.

On this basis, while it is reasonable to expect that stock markets are profoundly influenced by oil price changes, remarkably little empirical evidence exists. Hammoudeh et al. (2004, p. 428), for example, argues “...there has been a large volume of work investigating the links among international financial markets, and some work has also been devoted to the relationships among petroleum spot and futures prices. In contrast, little work has been done on the relationship between oil spot/futures prices and stock indices". This echoes similar sentiments by Sardorsky (1999, p. 450): “...in sharp contrast to the volume of work investigating the link between oil price shocks and macroeconomic variables, there has been relatively little work done on the relationship between oil price shocks and financial markets".

Even the findings of the extant work are mixed. Chen et al. (1986) and Hamao (1988) found no evidence of an oil price factor in the U.S. and Japan, respectively. In contrast, Sardorsky (1999) and Kaneko and Lee (1995) concluded that oil prices were a significant factor in the U.S. and Japan, respectively. Jones and Kaul (1996), Faff and Brailsford (1999), Sardorsky and Henriques (2001), Sardorksy (2001), Hammoudeh et al. (2004), Huang et al. (2005) and El-Sharif et al. (2005) have also examined the impact of oil price factors with disparate results. While these studies have provided at least some evidence that oil prices constitute a source of systematic asset price risk, and that the exposure to this risk varies across industries, no recent work is known in the Australian context.

The purpose of this paper is to build upon this work and examine the impact of oil prices on Australian monthly industry stock returns for the twenty-six years from January 1980 to August 2006. The remainder of the paper is divided into five main areas. Section 2 discusses the empirical methodology used. Section 3 provides a description of the data employed in the analysis. Section 4 presents some brief descriptive statistics. The results are dealt with in Section 5. The paper ends with some concluding remarks in Section 6. 


\section{Model specification}

The central aim of this analysis is to determine whether macroeconomic information, specifically crude oil prices, provides incremental information beyond the market portfolio regarding the behaviour of industry stock returns. While at least some work has been conducted at the market level [see, for example, Chen et al. (1986), Hamao (1988) and Cheung and Ng (1998)] relatively few studies have attempted to investigate the relationship between macroeconomic factors and stock returns at the industry level. To model the relationship between the macroeconomic factors and industry returns, a multifactor model following Khoo (1994), Chan and Faff (1998), Faff and Brailsford (1999), Sadorsky (2001) and Sardorsky and Henriques (2001) is employed:

$$
r_{i t}=\beta_{i 0}+\beta_{i 1} m k t_{t}+\beta_{i 2} \text { oil }_{t}+\beta_{i 3} f_{t}+\beta_{i 4} t r m_{t}+\beta_{i 5} \mathrm{crsh}_{t}+\varepsilon_{i t}
$$

where $r_{i t}$ denotes the return on the stock index of the ith industry at time $t, m k t_{t}$ is the return on the market portfolio, oil $l_{t}$ is the change in oil prices, $f x_{t}$ is the change in the exchange rate, $t_{r m}$ is the change in the term premium, $\beta_{i}$ are parameters to be estimated that are expected to vary by industry, $c r s h_{t}$ is a dummy variable used to capture the systemic effects of the October 1987 stock market crash and $\varepsilon_{\text {it }}$ is the error term.

Two main specification issues are noted. First, while industry stock returns are readily available at a daily frequency, the same cannot be said of most macroeconomic factors. As Groenewold and Fraser (1997 p. 1377) found “...data limitations restricted the choice of variables since several obvious choices...are not available at the monthly frequency". Specifying oil prices, exchange rates and the term premium enables the analysis to be conducted at a monthly frequency and provides consistency with previous work by Sadorsky (2001), Sardorsky and Henriques (2001) and El-Sharif et al. (2005). Second, the bulk of past research has assumed that stock markets and macroeconomic factors move contemporaneously [see, for example, Faff and Brailsford (1999), Sadorsky (2001), El-Sharif et al. (2005)]. However, intuition suggests that the impact of oil price changes on industry returns may not be instantaneous. To allow for persistence in the oil price factor, a dynamic model is specified where three one-period lagged prices are added to Equation (1). The choice of lag length is, of course, purely subjective. However, one to three month lags should represent sufficient time for the impact of oil prices to feed into the market.

\section{Data and variable definitions}

To investigate the relationship between macroeconomic variables and industry stock returns, monthly data over the period December 1979 to August 2006 is employed (320 observations). The choice of a monthly frequency is consistent with previous work which investigates macroeconomic variables in relation to stock returns [see, for example, Chan and Faff (1998), Faff and Brailsford (1999), Sadorsky (2001) and Manolis et al. (2002)]. All data is sourced from Global Financial Data (2006).

\subsection{Industry returns}

Two alternative measures of stock returns are typically employed in multifactor pricing models: raw returns [see Flannery and James (1984), Jorion (1990), Khoo (1994), Faff and Brailsford (1999), Chan and Faff (1998) and Di Iorio and Faff (2000)] and excess stock returns [see Sadorsky (2001), Sardorsky and Henriques (2001) and El-Sharif et al. (2005)]. Since only the return in excess of the risk-free rate is of concern in pricing models, excess stock returns are specified. The excess return in each industry is calculated as 
$r_{\mathrm{it}}=\ln \left[\frac{i n d_{\mathrm{it}}}{i n d_{\mathrm{i}, \mathrm{t}-1}}\right]-r f r_{t}$ where, $r_{\mathrm{it}}$ is the continuously compounded monthly return for industry $i$ at time $t$, ind $d_{\mathrm{it}}$ and $i n d_{\mathrm{i}, \mathrm{t}-1}$ are the index prices for industry $i$ at time $t$ and $t-1$, respectively, and $r f r$ denotes the risk-free rate of interest. To proxy the risk-free rate of interest, the monthly yield on Australian 90-day bank accepted bills is specified following Groenewold and Fraser (1997).

Nine industries comprising stocks listed on the Australian Securities Exchange (ASX) are employed in this study: namely, banking, diversified financials, energy, insurance, materials, media, property trusts, retailing and transport. While not an exhaustive list, the chosen indices are broad in their representation of cross-sectional differences in Australian industries. This is the longest period industry indices are available because the ASX in association with Standard and Poor's (S\&P) introduced new indices based upon the Global Industry Classification Standard (GICS) in April 2000. Regrettably, just a few sub-market series have been spliced together by Global Financial Data (2006) from the post-April 2000 ASX/S\&P series and the pre-April 2000 ASX series.

\subsection{Market returns}

A market portfolio is often used in research relating macroeconomic factors to industry and firm returns. The inclusion of the market portfolio as a source of market-wide systematic asset-price risk enables the determination of whether the macroeconomic data provides additional information regarding the behaviour of equity prices, in addition to that already captured by movements in the market portfolio. Traditionally, a broad-based value-weighted stock index of the local country is used to proxy for the market portfolio: in an Australian context, the All Ordinaries index is most suited. The excess return on the market portfolio is calculated as $m k t_{\mathrm{t}}=\ln \left[\frac{a o i_{\mathrm{it}}}{a o i_{\mathrm{it}-1}}\right]-r f r_{t}$ where $m k t_{\mathrm{t}}$ is the continuously compounded monthly return for the aggregate market index at time $t, a o i_{t}$ and $a o i_{\mathrm{t}-1}$ are the values for the market index at time $t$ and $t-1$, respectively, and $r f r_{\mathrm{t}}$ is the risk-free rate of interest.

\subsection{Oil prices}

Oil prices comprise the macroeconomic risk factor of most interest in this study. In general, oil price movements have the potential to influence equity price returns through their impact on future cash flows and indirectly through discount rates. To proxy for oil price effects, West Texas Intermediate crude oil prices are specified. USD prices are employed as an exchange rate variable is also incorporated in the models. Consequently, this enables the analysis to distinguish between pure oil price effects and pure exchange rate effects. The oil price factor is constructed as oil $_{\mathrm{t}}=\ln \left[\frac{w t x_{\mathrm{t}}}{w t x_{\mathrm{t}-1}}\right]$ where, oil $\mathrm{t}$ is the log monthly change in the oil price at time $t$, and $w t x_{\mathrm{t}}$ and $w t x_{\mathrm{t}-1}$ is the respective price of oil at time $t$. In line with Chen $e t$ al. (1986) and Hamao (1988), innovations in the oil price return series are ignored. Supportive evidence is found in the previous empirical work by Faff and Brailsford (1999), who find that the analysis of an oil price factor within the Australian stock market is qualitatively robust regardless of whether innovations or raw data is used.

\subsection{Exchange rates}

The AUD/USD exchange rate is also typically employed as a source of systematic asset price risk. The choice of the AUD/USD exchange rate to proxy for Australian foreign 
exchange risk is generally supported in the literature. For example, Di Iorio and Faff (2000) rationalise their choice of the AUD/USD exchange rate by pointing out that the United States is one of Australia's largest trading partners and that 55 percent of all Australian export contracts are written against the US dollar. Monthly values for the exchange rate over the period December 1989 to August 2006 are employed. The exchange rate factor is constructed as: $f x_{t}=\ln \left[\frac{\text { aud } / \text { usd }_{\mathrm{t}}}{\text { aud } / \text { usd }} \mathrm{t-1}\right]$ where $f x_{\mathrm{t}}$ is the log monthly change in the AUD/USD exchange rate at time $t$, and aud / $u s d_{\mathrm{t}}$ is the respective AUD/USD exchange rate at time $t$ and time $t-1$ [see Asprem (1989), Faff and Brailsford (1999), Di Iorio and Faff (2000), Sadorsky (2001) and El-Sharif et al. (2005)]. The AUD/USD exchange rate is expressed as the US dollar price of one Australian dollar: a positive (negative) value indicates an appreciation (depreciation) of the Australian dollar against the U.S. dollar.

\subsection{Term premium}

The term structure of interest rates (or term premium) has been extensively used in studies relating macroeconomic variables to stock returns. In turn, the term premium is basically defined as the difference between long- and short-term interest rates. For the purposes of this analysis, the annualised yield on Australian 10-year government bonds serves as the proxy for long-term interest rates (ltb) and the annualised yield on Australian 90-day bank-accepted bills as the proxy for short-term rates $(b a b)$. The change in the term premium is then defined as $t r m_{\mathrm{t}}=\left(l t b_{\mathrm{t}}-b a b_{t}\right)-\left(l t b_{\mathrm{t}-1}-b a b_{t-1}\right)$ where $(l t b-b a b)$ is the term premium at times $t$ and $t-$ 1, respectively. This specification follows work by Chen et al. (1986), Hamao (1988) and Aprem (1989), amongst others.

\section{Descriptive statistics}

Table I presents a summary of descriptive statistics of the monthly excess industry and market returns and the changes in the macroeconomic factors. The sample means, medians, standard deviations, skewness, kurtosis, Jacque-Bera test statistics for normality, and Augmented Dickey-Fuller and Phillips-Perron unit root tests are reported. By and large, the distributional properties of the industry return series appear non-normal. All series are significantly negatively skewed, indicating the greater probability of large deceases in returns than rises. The kurtosis, or degree of excess, in all return series is also significantly large, thereby indicating leptokurtic distributions with many extreme observations.

\section{$<$ TABLE I HERE $>$}

Jarque-Bera statistics are used to formally test the null hypotheses that the daily distribution of returns is normally distributed. All $p$-values are smaller than the .01 level of significance suggesting the null hypothesis can be rejected. None of these return series are then well approximated by the normal distribution. A similar distributional picture emerges for the macroeconomic factors. The exchange rate and the market portfolio returns are significantly negatively skewed, and while the statistics for the oil price and term premium factor series suggest positive skewness, they are not statistically significant. The kurtosis for all of the macroeconomic factors is significant, thereby indicating leptokurtosis. The nonnormal properties of the data are further confirmed via Jarque-Bera tests for normality, which are significant in each instance.

To test for stationarity the Augmented Dickey-Fuller (ADF) and the Phillips-Perron (PP) unit-root tests are employed. The ADF test is conducted at a lag length of four while the PP test is carried out using a truncation lag parameter of five. All tests include an intercept. The 
calculated values of the ADF and PP test statistics reject the null hypothesis of a unit root at the one-percent level of significance: all of the excess return series are stationary and suitable for regression-based analysis. One final concern in a multifactor modelling analysis of this type is the hypothesised presence of multicollinearity. Variance inflationary factors (VIF) (not shown) are calculated, but in no instance does the VIF for any of the macroeconomic factors approach even the most restrictive critical value (VIF $>5$ ). This suggests that multicollinearity, while present, is not too much of a problem.

\section{Empirical results}

Market models augmented by an oil price, exchange rate and term premium factor are estimated with ordinary least squares over the period 1980M01 to 2006M08 (320 observations) for each of the nine industries. The estimated coefficients, standard errors and $p$-values of the parameters detailed in Equation (1) are presented in Table II. Table II also includes the $\mathrm{R}^{2}$, the adjusted $\mathrm{R}^{2}$ from a single-factor market model, and an F-test of the null hypothesis that all slope coefficients are jointly zero and its $p$-value.

\section{<TABLE II HERE>}

Breusch-Godfrey Lagrange multiplier and White's heteroskedasticity tests (not shown) were initially used to test for higher-order serial correlation and heteroskedasticity in the least squares residuals, respectively. The null hypothesis of no serial correlation is rejected for all nine models and we may conclude the presence of higher-order serial correlation in the residuals. Then the null hypothesis of no heteroskedasticity in the least squares residuals fails to be rejected and we conclude the presence of heteroskedasticity in the least squares residuals. Accordingly, all standard errors and p-values in Table II incorporate corrections for heteroskedasticity and autocorrelation following Newey-West. The estimated models are all highly significant at the one-percent level, as indicated by the $F$-statistics and associated $p$ values. The values of $\mathrm{R}^{2}$ ranges between 0.3987 (media) and 0.6933 (materials), indicating that between 40 and 70 percent of the variation in excess industry stock returns is accounted for by the models. Hence, the models appear to fit the data relatively well.

The constant term in all nine estimated models is insignificant with the exception of the property trusts industry. The statistical insignificance of the constant term is consistent with previous empirical studies of stock returns and macroeconomic factors [see, for example, Faff and Brailsford (1999), Sadorsky and Henriques (2001) and Manolis et al. (2002)]. The dummy variable used to capture the effects of the October 1987 stock market crash is found to be significant in seven of the nine regressions (the media and materials industries are the exceptions). This provides complementary evidence to Faff and Brailsford (1999) in the need to specify market outliers in similar time-series analyses.

As expected, the market index excess return is highly significant in all regressions at the one-percent level of significance. The strong explanatory power of the market portfolio excess return in explaining fluctuations in industry excess stock returns is consistent with the earliest work on the capital asset pricing model. Interestingly, the estimated market index coefficients exceed unity in the energy (1.1654), materials (1.2736) and media (1.0602) industries, indicating that these industries are relatively more risky than the market. Conversely, the market parameters for the remaining industries are all less than unity, indicating that they are relatively less risky than the market.

In terms of the sensitivity of Australian industry returns to the oil price factor, the estimated coefficient (in brackets) is significant in four of the nine models; namely, the banking (-0.0676), energy (0.2576), retailing $(-0.0401)$ and transportation $(-0.0699)$ 
industries. Interestingly, the sensitivity of banking stocks to an oil price factor appears to be an exclusively Australian phenomenon (Faff and Brailsford 1999). One possible explanation for the association between oil prices and excess returns in the banking industry stems from the ostensible role of bank stocks in investor portfolios. In general, banking stocks are regarded as relatively safe investments (a claim supported by the market coefficient for the banking index being less than one). When the price of oil rises - a development generally believed to be beneficial for firms within the energy industry - shareholders increase the proportion of their portfolios invested in energy stocks.

Consequently, and assuming equilibrium in investor portfolios, it is plausible that investors shift out of less-risky assets (i.e. banking stocks) and invest a greater proportion of their wealth in riskier assets expected to benefit from the oil price rise (i.e. energy stocks). The sale of less-risky (bank) stocks then drives prices (and returns) down, and the prices of risky (energy) stocks are driven upwards. An alterative argument is provided by Faff and Brailsford (1999). They propose that the profitability of business banking customers has a strong impact on the profitability of bank stocks. Consequently, if we assume that the profitability of many bank customers is inversely related to oil prices, a negative and significant oil price coefficient for the banking industry can also be partly explained.

Excess returns in the retailing industry are also negatively related to the oil price factor. A possible explanation for the observed negative effect is the influence of oil price increases on consumer discretionary spending. As the price of oil rises relative to other goods and as a proportion of household expenditure, the nondiscretionary nature of household petroleum expenditure, at least in the short-run, limits the amount of discretionary funds available to consumers. This should lower the returns on retail firms. The remaining industries in the analysis do not exhibit sensitivity to the oil price factor.

Previous empirical evidence suggests that the association between exchange rates and stock returns is both country and industry specific. Hamao (1988) concluded that the foreign exchange rate is not priced in the Japanese market, while Sadorsky (2001) and Sadorsky and Henriques (2001) found that the exchange rate is priced for some Canadian industries. Given the significance of international trade to the Australian economy, an exchange rate variable was incorporated in the model specification. The estimated regressions indicate that the coefficients for the AUD/USD exchange rate are significant for the banking (0.1796) and diversified financials (0.1422) industries. Following Sadorsky (2001), the positive signs suggest that an appreciation of the Australian dollar improves the revenues of these industries more than it increases costs. These findings are consistent with earlier Australian work on exchange rates and industry returns [see, for example, Di Iorio and Faff (2000)].

To proxy for changes in the yield curve a term premium variable was specified, defined as the monthly change in the spread between long and short-term interest rates. Three industries exhibit significant association with the term premium: namely, energy (0.5703), insurance ($0.5260)$ and retailing $(-0.4810)$. The positive coefficient on the energy index is consistent with the hypothesis that the term premium is positively related to future real activity and business cycles. This is because the term premium is generally lower near and during peaks and higher near and during troughs (Chen, 1991). But contrary to this conventional hypothesis, the term premium coefficient on the insurance and retailing industries is negative. The negative coefficient indicates that the excess stock returns of these industries are inversely related to the spread between long and short-term rates, suggesting that these industries move counter-cyclically with the economy. Chen et al. (1986) suggest an alternative explanation. They argue that the term premium measures the changes in the real rate of interest. As such, stocks whose returns are negatively correlated with the term 
premium, and hence the real rate of interest, will be move valuable (Chen et al., $1986 \mathrm{pp}$. 395-397):

After long-term real rates decrease, there is subsequently a lower real return on any form of capital. Investors who want protection against this possibility will place a relatively higher value on assets whose price increases when long-term real rates decline, and such assets will carry a negative risk premium. Thus, stocks whose returns are correlated with long-term bonds... .... will be more valuable than stocks that are uncorrelated or negatively correlated with long-term bond returns.

Given that the insurance and retail industries' excess returns are negatively related to the term premium, and therefore the long-term real rate of interest, a decrease (increase) in the spread between long and short-term rates leads investors to demand more (less) of the stocks in these industries. As the price increases (decreases) with increasing (decreasing) investor demand, the excess return of these industries will increase (decrease), thus providing a plausible explanation for the negative term premium coefficient.

Together, these results suggest that macroeconomic factors are an important factor in the explanation of excess stock returns at the industry level. Further evidence can be gained by comparing the $\mathrm{R}^{2}$ of these regressions with an adjusted $\mathrm{R}^{2}$ obtained with the market portfolio as the sole explanatory variable. As shown in Table II, macroeconomic factors improve the ability to explain fluctuations in industry excess stock returns by 0.8 percent in the materials industry, 1.07 percent for media, 1.39 percent for transport, 1.61 percent for property, 1.62 percent for insurance, 2.00 percent for retailing, 2.22 percent for banking and 2.78 percent for diversified financials. Of special note is the incremental value of the macroeconomic factors for explaining and predicting returns in the energy industry. Here the inclusion of the oil price, exchange rate and term premium factors improves our ability to account for fluctuations in excess returns by about 9.05 percent. Overall, the results support the general inclusion of macroeconomic factors in asset pricing models.

One final methodological requirement is to estimate a dynamic regression model to investigate the relationship between excess stock returns in each industry and lagged oil prices. Included in these models are excess returns on the market portfolio, the change in the contemporaneous oil price and one, two and three-period lagged oil price changes. A dummy variable for the 1987 stock market crash is also included. The regression is estimated for each of the nine industries for the entire sample and for each of the following sub-periods: 1980M01-1985M12, 1986M01-1990M07, 1990M08-1999M03 and 1999M04-2006M08 (results not shown). While somewhat arbitrary, the breaks are selected (and tested for significance using Chow breakpoint tests) to coincide with the 1986 oil price collapse, the Iraqi invasion of Kuwait in August 1990 and the uncertainty concerning Middle Eastern oil supplies, and the start of a series of significant OPEC production interventions in April 1999.

\section{$<$ TABLE III HERE >}

Table III displays the estimated coefficients and standard errors for each of the nine industries over the entire sample period. As before, industries with significant contemporaneous oil price impacts include the banking, energy and transport industries. The energy industry also exhibits a significant lagged effect at the one and two-month lags, indicating that the oil price effects in this industry are persistent. Other industries found to possess lagged dependencies to oil price movements include materials (three-month lag), media (one-month lag), retail (one and three-month lags) and transportation (one-month lag). 
Interestingly, excess returns for the retail industry are affected more by oil price increases three months previously than by price increases one month previous, suggesting that oil price changes gradually filter their way through the economy and into the performance of retail companies over several months. The results for the sub-period analysis are generally consistent with those of the full period analysis in terms of the magnitude and significance of the contemporaneous and lagged oil price coefficients. However, across all industries the proportion of variability in excess industry returns explained by oil price factors has generally fallen with each successive sub-period.

\section{Conclusion}

This study examines the impact of macroeconomic risk factors on Australian industry returns. Time-series regressions indicate that macroeconomic factors - including the market portfolio, oil prices, exchanges rates and the term premium - are important determinants of excess returns for many industries. Of the nine industries considered, the energy industry exhibited a strong positive association with oil price increases, while the banking, retailing and transportation industries showed significantly negative associations with oil prices. While the negative oil price coefficient were expected for the transportation and retail industries, along with the positive coefficient for the energy industry, the significantly negative coefficient for the banking industry is a surprising finding. We suggest that this is because of the role of bank stocks as a defensive investment. Accordingly, and assuming equilibrium in investor portfolios, an increase (decrease) in the price of oil will trigger investors to sell (buy) banking stocks and buy (sell) energy stocks, thus accounting for the respective negative and positive coefficients.

Given the importance of the oil price factor, a dynamic regression model was also employed to investigate the relationship between lagged oil prices and excess stock returns and some interesting results were found. For example, the retail industry showed a significant oil price effect at one and three-month lags, suggesting that oil price increases gradually feed their way into the economy. The results of a sub-period analysis indicated that the relationship between oil prices and excess stock returns has diminished over time, suggesting a change in oil price dynamics over the longer-term.

Some variation is also found in the influence of the remaining macroeconomic factors on industry returns. As per theoretical expectations, the market portfolio is a significant pricing factor in all industry excess returns, with the energy, materials and media industries being proportionally more volatile (risky) than the market and banking, diversified financial, insurance, property trusts, retailing and transport being less risky. Exchanges rates are also found to be an influential factor for excess returns in the banking and diversified financials industries, and the term premium as a proxy for future real activity is a priced factor in the energy, insurance and retailing industries. Overall, we conclude that macroeconomic factors are an important determinant of asset price returns in Australia.

\section{References}

Australian Bureau of Agricultural and Resource Economics (2005), Australian Commodity Statistics, Canberra, Commonwealth of Australia.

Australian Bureau of Statistics (2001), Australia National Accounts Input-Output Tables, Canberra, Australian Bureau of Statistics.

Antoniou, A., Garrett, I. and Priestley, R. (1998), "Macroeconomic variables as common pervasive risk factors and the empirical content of the arbitrage pricing theory". Journal of Empirical Finance, Vol. 5 No. 3, pp. 221-240. 
Apergis, N. and Eleftheriou, S. (2002), "Interest rates, inflation, and stock prices: the case of the Athens stock exchange”, Journal of Policy Modeling, Vol. 24 No. 3, pp. 231-236.

Asprem, M. (1989), "Stock prices, asset portfolios and macroeconomic variables in ten European countries", Journal of Banking and Finance, Vol. 13 No. 4/5, pp. 589-612.

Canova, F. and Nicolo, G.D. (2000), "Stock returns, term structure, inflation, and real activity: an international perspective”, Macroeconomic Dynamics, Vol. 4 No. 3, pp. 343-372.

Chan, H. and Faff, R. (1998), "The sensitivity of Australian industry equity returns to a gold price factor", Accounting and Finance, Vol. 38 No. 2, pp. 223-244.

Chaudhuri, K. and Smiles, S. (2004), "Stock market and aggregate economic activity: evidence from Australia", Applied Financial Economics, Vol. 14 No. 2, pp. 121-129.

Chen, N.-F., Roll, R., and Ross, S.A. (1986), “Economic forces and the stock market”, Journal of Business, Vol. 59 No. 3, pp. 383-403.

Cheung, Y.-W. and Ng, L.K. (1998), "International evidence on the stock market and aggregate economic activity”, Journal of Empirical Finance, Vol. 5 No. 3, pp. 281-296.

Choi, J.J., Elyasiani, E. and Kopecky, K.J. (1992), "The sensitivity of bank stock returns to market, interest and exchange rate risks", Journal of Banking and Finance, Vol. 16 No. 5, pp. 983-1004.

Di Iorio, A. and Faff, R. (2000), "An analysis of asymmetry in foreign currency exposure of the Australian equities market”, Journal of Multinational Financial Management, Vol. 10 No. 2, pp. 133-159.

Dinenis, E., and Staikouras, S.K. (1998), "Interest rate changes and common stock returns of financial institutions: evidence from the UK, The European Journal of Finance, Vol. 4 No. 2, pp. 113-127.

El-Sharif, I., Brown, D., Burton, B., Nixon, B. and Russell, A. (2005), "Evidence on the nature and extent of the relationship between oil prices and equity values in the UK”, Energy Economics, Vol. 27 No. 6, pp. 819830.

Elyasiani, E., and Mansur, I. (1998). Sensitivity of the bank stock returns distribution to changes in the level and volatility of interest rate: a GARCH-M model”, Journal of Banking and Finance, Vol. 22 No. 5, pp. 535563.

Erdem, C., Arslan, C.K. and Sema Erdem, M. (2005), "Effects of macroeconomic variables on Istanbul stock exchange indexes”, Applied Financial Economics, Vol. 15 No. 14, pp. 987-994.

Faff, R., and Brailsford, T. (1999), “Oil price risk and the Australian stock market”, Journal of Energy Finance and Development, Vol. 4 No. 1, pp. 69-87.

Faff, R. and Chan, H. (1998), "A multifactor model of gold industry stock returns: evidence from the Australian equity market”, Applied Financial Economics, Vol. 8 No. 1, pp. 21-28.

Flannery, M.J. and James, C.M. (1984), "The effect of interest rate changes on the common stock returns of financial institutions”, Journal of Finance, Vol. 39 No. 4, pp. 1141-1153.

Groenewold, N. and Fraser, P. (1997), "Share prices and macroeconomic factors", Journal of Business Finance and Accounting, Vol. 24 No. 9/10, pp. 1367-1383.

Hamao, Y. (1988), “An empirical examination of the arbitrage pricing theory using Japanese data”, Japan and the World Economy, Vol. 1 No. 1, pp. 45-61.

Hammoudeh, S., Dibooglu, S. and Aleisa, E. (2004), "Relationships among U.S. oil prices and oil industry equity indices", International Review of Economics and Finance, Vol. 13 No. 4, pp. 427-453.

Huang, B.-N., Hwang, M.J. and Peng, H.-P. (2005), "The asymmetry of the impact of oil price shocks on economic activities: an application of the multivariate threshold model”, Energy Economics, Vol. 27 No. 3, pp. 455-476.

Jones, C.M. and Kaul, G. (1996), “Oil and the stock markets”, Journal of Finance, Vol. 51 No. 2, pp. 463-491.

Jorion, P. (1990), "The exchange-rate exposure of U.S. multinationals”, Journal of Business, Vol. 63 No. 3, pp. 331-345.

Kaneko, T., and Lee, B.-S. (1995), "Relative importance of economic factors in the U.S. and Japanese stock markets”, Journal of the Japanese and International Economies, Vol. 9 No. 3, pp. 290-307.

Khoo, A. (1994), "Estimation of foreign exchange exposure: an application to mining companies in Australia", Journal of International Money and Finance, Vol. 13 No. 3, pp. 342-363.

Manolis, G.K., Stelios, N.M. and Angelos, G.A. (2002), "Macroeconomic factors and international industry returns”, Applied Financial Economics, Vol. 12 No. 12, pp. 923-931. 
Patro, D.K., Wald, J.K. and Wu, Y. (2002), “The impact of macroeconomic and financial variables on market risk: evidence from international equity returns”, European Financial Management, Vol. 8 No. 4, pp. 421447.

Poon, S. and Taylor, S. (1991), "Macroeconomic factors and the UK stock market”, Journal of Business Finance and Accounting, Vol. 18 No. 5, pp. 619-636.

Ryan, S. and Worthington, A.C. (2004), "Market, interest rate and foreign exchange rate risk in Australian banking: a generalised autoregressive conditional heteroskedasticity in mean (GARCH-M) approach”, Journal of Applied Business and Economic Research, Vol. 2 No. 2, pp. 81-103.

Sadorsky, P. (1999), “Oil price shocks and stock market activity”, Energy Economics, Vol. 21 No. 5, pp. 449469.

Sadorsky, P. (2001), "Risk factors in stock returns of Canadian oil and gas companies”, Energy Economics, Vol. 23 No. 1, pp. 17-28.

Sadorsky, P. and Henriques, I. (2001), "Multifactor risk and the stock returns of Canadian paper and forest products companies”, Forest Policy and Economics, Vol. 3 No. 3/4, pp. 199-208.

West, T. and Worthington, A.C. (2006), "Macroeconomic risk factors in Australian commercial real estate, listed property trust and property sector stock returns: a comparative analysis using GARCH-M, Journal of Financial Management of Property and Construction, Vol. 11 No. 2, pp. 21-31. 


\begin{tabular}{|c|c|c|c|c|c|c|c|c|c|c|c|c|c|}
\hline Returns and factors & Mean & Median & Maximum & Minimum & Std. Dev. & Skewness & Kurtosis & $\begin{array}{c}\mathrm{JB} \\
\text { statistic }\end{array}$ & $\begin{array}{c}\text { JB } \\
p \text {-value }\end{array}$ & $\begin{array}{c}\mathrm{ADF} \\
\text { statistic }\end{array}$ & $\begin{array}{c}\text { ADF } \\
p \text {-value }\end{array}$ & $\begin{array}{c}\mathrm{PP} \\
\text { statistic }\end{array}$ & $\begin{array}{c}\text { PP } \\
p \text {-value }\end{array}$ \\
\hline Banking & 0.0022 & 0.0080 & 0.1840 & -0.3717 & 0.0564 & -0.8273 & 8.4629 & 434.4063 & 0.0000 & -8.9926 & 0.0000 & -18.1783 & 0.0000 \\
\hline Diversified financials & 0.0001 & 0.0030 & 0.1414 & -0.5434 & 0.0532 & -3.3648 & 35.6670 & 14832.2400 & 0.0000 & -8.1967 & 0.0000 & -16.6815 & 0.0000 \\
\hline Energy & -0.0007 & 0.0044 & 0.2864 & -0.5152 & 0.0808 & -0.9963 & 9.7524 & 660.8771 & 0.0000 & -7.3279 & 0.0000 & -15.2280 & 0.0000 \\
\hline Insurance & 0.0013 & 0.0026 & 0.1706 & -0.5294 & 0.0664 & -1.6329 & 15.2128 & 2130.9166 & 0.0000 & -6.9458 & 0.0000 & -18.0486 & 0.0000 \\
\hline Materials & -0.0036 & -0.0030 & 0.2621 & -0.7111 & 0.0845 & -1.7501 & 17.8812 & 3116.0054 & 0.0000 & -7.6728 & 0.0000 & -18.8014 & 0.0000 \\
\hline Media & 0.0045 & 0.0083 & 0.2395 & -0.5313 & 0.0877 & -1.0774 & 8.4648 & 460.0983 & 0.0000 & -8.3067 & 0.0000 & -15.8957 & 0.0000 \\
\hline Property trust & -0.0033 & -0.0028 & 0.0797 & -0.2827 & 0.0353 & -1.6193 & 14.6340 & 1944.5223 & 0.0000 & -9.4973 & 0.0000 & -18.4579 & 0.0000 \\
\hline Retail & 0.0003 & 0.0010 & 0.1936 & -0.5048 & 0.0581 & -1.8896 & 19.9081 & 4002.2043 & 0.0000 & -9.1635 & 0.0000 & -16.6624 & 0.0000 \\
\hline Transport & 0.0011 & 0.0048 & 0.2056 & -0.6159 & 0.0681 & -2.3323 & 23.0435 & 5646.6579 & 0.0000 & -10.0064 & 0.0000 & -18.2721 & 0.0000 \\
\hline Market portfolio & -0.0007 & 0.0037 & 0.1503 & -0.5637 & 0.0547 & -3.5047 & 37.0736 & 16135.2474 & 0.0000 & -8.2469 & 0.0000 & -18.0301 & 0.0000 \\
\hline Oil price & 0.0028 & 0.0027 & 0.3714 & -0.3525 & 0.0880 & 0.0067 & 6.1227 & 130.0192 & 0.0000 & -9.1934 & 0.0000 & -15.5293 & 0.0000 \\
\hline Exchange rate & -0.0012 & -0.0011 & 0.0778 & -0.1364 & 0.0294 & -0.7236 & 5.1927 & 92.0371 & 0.0000 & -8.5878 & 0.0000 & -17.0046 & 0.0000 \\
\hline Term premium & 0.0000 & -0.0003 & 0.0517 & -0.0512 & 0.0084 & 0.0842 & 14.5013 & 1764.1179 & 0.0000 & -9.3351 & 0.0000 & -19.5798 & 0.0000 \\
\hline
\end{tabular}

Table I.

Sample descriptive statistics 


\begin{tabular}{|c|c|c|c|c|c|c|c|c|c|c|}
\hline & & Banking & $\begin{array}{l}\text { Diversified } \\
\text { financials }\end{array}$ & Energy & Insurance & Materials & Media & $\begin{array}{c}\text { Property } \\
\text { trusts }\end{array}$ & Retailing & Transport \\
\hline \multirow{3}{*}{ 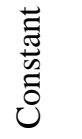 } & Coefficient & 0.0029 & 0.0013 & -0.0011 & 0.0022 & -0.0028 & 0.0051 & -0.0029 & 0.0013 & 0.0022 \\
\hline & Standard error & 0.0023 & 0.0018 & 0.0027 & 0.0032 & 0.0026 & 0.0041 & 0.0014 & 0.0023 & 0.0022 \\
\hline & $p$-value & 0.2056 & 0.4673 & 0.6874 & 0.4870 & 0.2779 & 0.2067 & 0.0479 & 0.5753 & 0.3140 \\
\hline \multirow{3}{*}{ 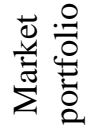 } & Coefficient & 0.7777 & 0.6429 & 1.1654 & 0.7371 & 1.2736 & 1.0602 & 0.3785 & 0.6794 & 0.9262 \\
\hline & Standard error & 0.0593 & 0.0638 & 0.1052 & 0.1075 & 0.0586 & 0.1310 & 0.0412 & 0.0639 & 0.0569 \\
\hline & $p$-value & 0.0000 & 0.0000 & 0.0000 & 0.0000 & 0.0000 & 0.0000 & 0.0000 & 0.0000 & 0.0000 \\
\hline \multirow{3}{*}{$\overline{0} . \stackrel{\mathscr{U}}{0}$} & Coefficient & -0.0676 & -0.0075 & 0.2576 & -0.0414 & 0.0386 & -0.0738 & -0.0173 & -0.0401 & -0.0699 \\
\hline & Standard error & 0.0225 & 0.0195 & 0.0253 & 0.0427 & 0.0423 & 0.0585 & 0.0159 & 0.0237 & 0.0262 \\
\hline & $p$-value & 0.0028 & 0.7000 & 0.0000 & 0.3332 & 0.3615 & 0.2085 & 0.2785 & 0.0916 & 0.0081 \\
\hline \multirow{3}{*}{ 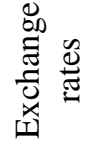 } & Coefficient & 0.1796 & 0.1422 & -0.0461 & 0.0089 & 0.0842 & -0.1277 & -0.0253 & 0.0453 & 0.0047 \\
\hline & Standard error & 0.0750 & 0.0549 & 0.0872 & 0.1079 & 0.1061 & 0.1098 & 0.0563 & 0.0949 & 0.1005 \\
\hline & $p$-value & 0.0173 & 0.0101 & 0.5977 & 0.9344 & 0.4282 & 0.2458 & 0.6538 & 0.6336 & 0.9624 \\
\hline \multirow{3}{*}{ 园罜 } & Coefficient & 0.0654 & 0.0067 & 0.5703 & -0.5260 & 0.2419 & -0.2237 & 0.2681 & -0.4810 & 0.1280 \\
\hline & Standard error & 0.2649 & 0.2541 & 0.3131 & 0.2501 & 0.2628 & 0.3404 & 0.2033 & 0.2042 & 0.2328 \\
\hline & $p$-value & 0.8053 & 0.9791 & 0.0695 & 0.0363 & 0.3580 & 0.5117 & 0.1882 & 0.0191 & 0.5827 \\
\hline \multirow{3}{*}{ 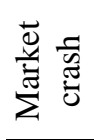 } & Coefficient & 0.0754 & -0.1745 & 0.1413 & -0.1203 & 0.0158 & 0.0534 & -0.0648 & -0.1249 & -0.0931 \\
\hline & Standard error & 0.0334 & 0.0361 & 0.0593 & 0.0604 & 0.0327 & 0.0744 & 0.0229 & 0.0357 & 0.0316 \\
\hline & $p$-value & 0.0246 & 0.0000 & 0.0177 & 0.0474 & 0.6281 & 0.4738 & 0.0049 & 0.0005 & 0.0034 \\
\hline \multirow{4}{*}{ 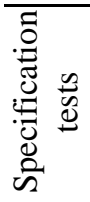 } & $\mathrm{R}^{2}$ & 0.5583 & 0.6467 & 0.6454 & 0.4465 & 0.6933 & 0.3987 & 0.4309 & 0.5163 & 0.6321 \\
\hline & Adjusted $\mathrm{R}^{2}$ & 0.5361 & 0.6189 & 0.5549 & 0.4303 & 0.6890 & 0.3880 & 0.4148 & 0.4963 & 0.6182 \\
\hline & $F$-statistic & 79.3918 & 114.9540 & 114.3207 & 50.6623 & 141.9344 & 41.6490 & 47.5419 & 67.0287 & 107.8859 \\
\hline & $p$-value & 0.0000 & 0.0000 & 0.0000 & 0.0000 & 0.0000 & 0.0000 & 0.0000 & 0.0000 & 0.0000 \\
\hline
\end{tabular}

Table II.

Estimated contemporaneous market model 


\begin{tabular}{|c|c|c|c|c|c|c|c|c|c|c|}
\hline & & Banking & $\begin{array}{l}\text { Diversified } \\
\text { financials } \\
\end{array}$ & Energy & Insurance & Materials & Media & $\begin{array}{c}\text { Property } \\
\text { trusts }\end{array}$ & Retailing & Transport \\
\hline \multirow{3}{*}{ 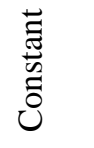 } & Coefficient & 0.0029 & 0.0008 & -0.0010 & 0.0021 & -0.0032 & 0.0058 & -0.0028 & 0.0017 & 0.0020 \\
\hline & Standard error & 0.0023 & 0.0018 & 0.0027 & 0.0033 & 0.0027 & 0.0041 & 0.0015 & 0.0023 & 0.0022 \\
\hline & $p$-value & 0.2076 & 0.6421 & 0.7086 & 0.5166 & 0.2318 & 0.1585 & 0.0576 & 0.4513 & 0.3698 \\
\hline \multirow{3}{*}{ 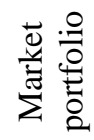 } & Coefficient & 0.8021 & 0.7001 & 1.1750 & 0.7893 & 1.2926 & 1.0602 & 0.3843 & 0.6882 & 0.9459 \\
\hline & Standard error & 0.0637 & 0.0556 & 0.1087 & 0.0938 & 0.0603 & 0.1151 & 0.0432 & 0.0571 & 0.0553 \\
\hline & $p$-value & 0.0000 & 0.0000 & 0.0000 & 0.0000 & 0.0000 & 0.0000 & 0.0000 & 0.0000 & 0.0000 \\
\hline \multirow{3}{*}{ 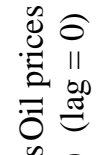 } & Coefficient & -0.0594 & -0.0003 & 0.2561 & -0.0356 & 0.0396 & -0.0646 & -0.0162 & -0.0282 & -0.0582 \\
\hline & Standard error & 0.0221 & 0.0186 & 0.0225 & 0.0448 & 0.0446 & 0.0482 & 0.0180 & 0.0247 & 0.0268 \\
\hline & $p$-value & 0.0076 & 0.9854 & 0.0000 & 0.4268 & 0.3749 & 0.1815 & 0.3698 & 0.2527 & 0.0305 \\
\hline \multirow{3}{*}{ 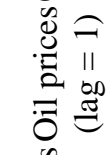 } & Coefficient & -0.0317 & -0.0226 & 0.0718 & -0.0159 & 0.0242 & -0.1134 & -0.0155 & -0.0588 & -0.0634 \\
\hline & Standard error & 0.0291 & 0.0208 & 0.0321 & 0.0304 & 0.0318 & 0.0680 & 0.0177 & 0.0271 & 0.0334 \\
\hline & $p$-value & 0.2767 & 0.2779 & 0.0261 & 0.6011 & 0.4478 & 0.0965 & 0.3809 & 0.0310 & 0.0584 \\
\hline \multirow{6}{*}{ 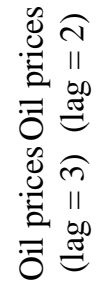 } & Coefficient & -0.0294 & -0.0068 & 0.0801 & 0.0215 & 0.0054 & -0.0332 & -0.0044 & 0.0126 & 0.0373 \\
\hline & Standard error & 0.0178 & 0.0171 & 0.0255 & 0.0346 & 0.0301 & 0.0454 & 0.0163 & 0.0215 & 0.0300 \\
\hline & $p$-value & 0.1003 & 0.6904 & 0.0018 & 0.5351 & 0.8581 & 0.4644 & 0.7847 & 0.5575 & 0.2153 \\
\hline & Coefficient & -0.0349 & -0.0180 & 0.0228 & -0.0438 & 0.0610 & -0.0023 & 0.0106 & -0.0794 & -0.0161 \\
\hline & Standard error & 0.0320 & 0.0180 & 0.0317 & 0.0336 & 0.0366 & 0.0444 & 0.0164 & 0.0280 & 0.0251 \\
\hline & $p$-value & 0.2759 & 0.3191 & 0.4722 & 0.1929 & 0.0967 & 0.9592 & 0.5198 & 0.0049 & 0.5230 \\
\hline \multirow{3}{*}{ 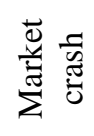 } & Coefficient & 0.0778 & -0.1494 & 0.1490 & -0.0822 & 0.0174 & 0.0584 & -0.0640 & -0.1135 & -0.0803 \\
\hline & Standard error & 0.0367 & 0.0316 & 0.0619 & 0.0542 & 0.0342 & 0.0658 & 0.0247 & 0.0328 & 0.0317 \\
\hline & $p$-value & 0.0345 & 0.0000 & 0.0167 & 0.1306 & 0.6104 & 0.3756 & 0.0101 & 0.0006 & 0.0119 \\
\hline \multirow{4}{*}{ 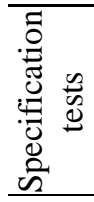 } & $\mathrm{R}^{2}$ & 0.5501 & 0.6621 & 0.6440 & 0.4698 & 0.6830 & 0.4202 & 0.4250 & 0.5365 & 0.6396 \\
\hline & Market Adj. $\mathrm{R}^{2}$ & 0.5414 & 0.6555 & 0.6371 & 0.4595 & 0.6769 & 0.4090 & 0.4139 & 0.5275 & 0.6326 \\
\hline & F-statistic & 63.1710 & 101.2310 & 93.4745 & 45.7778 & 111.3270 & 37.4511 & 38.1874 & 59.7984 & 91.6876 \\
\hline & $p$-value & 0.0000 & 0.0000 & 0.0000 & 0.0000 & 0.0000 & 0.0000 & 0.0000 & 0.0000 & 0.0000 \\
\hline
\end{tabular}

Notes: All regressions incorporate Newey and West (1987) heteroskedasticity and autocorrelation consistent standard errors. Lags in months. Adjusted $\mathrm{R}^{2}$ is the $\mathrm{R}^{2}$ of the model if the only the contemporaneous oil price is included as an explanatory variable.

Table III.

Estimated dynamic market model 